\title{
Inhibitory effects of Porphyra den- tata extract on 3T3-L1 adipocyte differentiation
}

\author{
Su-Young Choi ${ }^{1 \#}$, Su Yeon Lee ${ }^{2 \#}$, Da hye Jang ${ }^{2}$, Suk Jun Lee ${ }^{3}$, Jeong-Yong Cho ${ }^{2 \star}$ \\ and Sung-Hak Kim ${ }^{1 *}$ \\ ${ }^{1}$ Department of Animal Science, Chonnam National University, Gwangju 61186, Korea \\ ${ }^{2}$ Department of Food Science and Technology, Chonnam National University, Gwangju 61186, Korea \\ ${ }^{3}$ Department of Biomedical Laboratory Science, College of Health \& Medical Sciences, Cheongju University, \\ Chungbuk 28503, Korea
}

\begin{abstract}
This study was aimed to investigate the inhibitory effects of Porphyra dentata ( $P$. dentata) extract on the adipogenesis of 3T3-L1 cells and evaluate its anti-obesity effect. The proliferation of 3T3-L1 cells and differentiation of adipocytes under treatment of $P$. dentata extract was examined by measuring the cell viability using alamarBlue assay and lipid droplets by Oil Red O staining. Results showed that $P$. dentata extract has no cytotoxicity effect and lipid droplets formation decreased in a concentration-dependent manner in 3T3-L1 cells. It has been confirmed that transcription factors affecting lipid accumulation and anti-adipogenic effects during cell differentiation are linked to $P$. dentata extract. We observed that $P$. dentata shows lowering the mRNA expression of peroxisome proliferator-activated receptor y2 (PPARy2), CCAAT/enhancer binding protein $\alpha(\mathrm{C} / \mathrm{EBP} \alpha)$ that adipogenesis-associated key transcription factors and inhibiting adipogenesis in the early stages of differentiation. Treating the cells with P. dentata did not only suppressed PPARY2 and C/EBPa but also significantly decreased the mRNA expression of adiponectin, Leptin, fatty acid synthase, adipocyte protein 2, and Acetyl-coA carboxylase 1. Overall, the $P$. dentata extract demonstrated inhibitory property in adipogenesis, which has a potential effect in anti-obesity in 3T3-L1 cells.

Keywords: 3T3-L1, Adipocyte differentiation, Adipogenesis, Porphyra dentata, Anti-obesity
\end{abstract}

\section{INTRODUCTION}

Obesity is one of the biggest health problems in the world today and the number of obese people are increasing in all over the world [1,2]. Obesity is defined as an increase in body weight [3] caused excessive accumulation of fat cells due to adipocyte differentiation [4]. Hence, it is also closely linked to metabolic diseases such as type 2 diabetes (T2D), liver disease, cardiovascular disease (CVD), cancers, hypertension and other disorders which increased these disease occurrence [5,6]. Accumulation of fat cells that cause obesity is by the differentiation of adipocytes called adipogenesis. Peroxisome proliferator-activated receptor $\gamma(\mathrm{PPAR} \gamma)$ and CCAAT/enhancer-binding protein (C/EBP) transcription factor family are key players to regulate the differentiation of preadipocytes by inducing adipogenic related 
Jeong-Yong Cho

https://orcid.org/0000-0002-2048-5661

Sung-Hak Kim

https://orcid.org/0000-0003-4882-8600

\section{Competing interests}

No potential conflict of interest relevant to

this article was reported.

Funding sources

This research was supported by Basic

Science Research Program through the

National Research Foundation of Korea

(NRF) funded by the Ministry of Education,

Science and Technology (no. NRF-

2019R1/1A3A01059211)

Acknowledgements

We thank the members of the Kim laboratory

for their discussions and help.

Availability of data and material

Upon reasonable request, the datasets

of this study can be available from the

corresponding author.

Authors' contributions

Conceptualization: Cho JY, Kim SH.

Data curation: Cho JY, Kim SH.

Formal analysis: Choi SY, Lee SY, Cho JY, $\mathrm{Kim} \mathrm{SH}$.

Methodology: Choi SY, Lee SY, Jang Dh,

Lee SJ.

Writing - original draft: Choi SY.

Writing - review \& editing: Cho JY, Kim SH.

Ethics approval and consent to participate This article does not require IRB/IACUC approval because there are no human and animal participants. genes including adiponectin (ADIPOQ), leptin, fatty acid synthase (FAS), adpocyte protein 2 (aP2), and acetyl-coA carboxylase 1 (ACC) [7-10].

Laver, an edible seaweed species belonging to the genus Porphya, is commonly grown and consumed in Korea, China, and Japan. Laver is a rich source of vitamins, minerals, polysaccharides, phenolic compounds and mycosporine-like amino acids (MAAs) [11]. The polysaccharides components include laminarin and fucoidan while phenolic compounds present includes epigallocatechin gallate (EGCG) and catechin. Moreover, MAAs present in laver are mycosporine, shinorine, and porphyra-334. Several studies have shown that laver has antioxidant [12], anti-ultraviolet [13], anti-inflammatory [14], and antitumor [15] effects because of its bioactive compounds present. Marine algae, especially seaweeds are a promising source of anti-obesity agent [16] and anti-obesity effects are reported in various kinds of seaweed (brown, red and green) [17]. Also polysaccharides and phenol compounds are also reported to have anti-obesity effects $[18,19]$.

Porphyra dentata ( $P$. dentata) used in this study, is a kind of red algae and belongs to the Bangiaceae and Pyropia genus and an edible red seaweed in eastern Asian countries [20]. P. dentata contains polysaccharides and phenolic compound such as fucoidan, EGCG, and catechin [21]. It was reported that it has anti-inflammatory activity by suppressing nitric oxide production in LPS-stimulated macrophage [21]. As reported, although the components of $P$. dentata have a potential to regulate adipogenesis, anti-obesity effect on this extract have not been addressed.

The purpose of this study is to evaluate whether the $P$. dentata extract has inhibitory effects on adipogenesis from preadipocyte to mature adipocyte in 3T3-L1 cells.

\section{MATERIALS AND METHODS}

\section{Chemicals and cell}

Dulbecco's Modified Eagle's Medium (DMEM; high glucose) was purchased from Hyclone ${ }^{\mathrm{TM}}$ (Logan, UT, USA). Fetal bovine serum (FBS) were purchased from Gibco-BRL (Gaithersburg, MD, USA). 3-Isobutyl-1-methylxanthine (IBMX), dexamethasone (DEX), pioglitazone, insulin, Oil Red O powder, and dimethyl sulfoxide (DMSO) were purchased from Sigma-Aldrich (St. Louis, MO, USA). Formaldehyde Solution for $4 \%$ formalin was purchased from Fujifilm Wako Pure Chemical (Osaka, Japan). 2-propanol-GR and ethanol were purchased Merck (Kenilworth, NJ, USA). The 3T3-L1 cells were purchased from American Type Culture Collection (Rockville, CT,USA).

\section{Preparation of the Porphyra dentata extract}

Dried P. dentata was obtained from Mokpo Marine Food-industry Research Center (Mokpo, Korea). The dried $P$. dentata $(50 \mathrm{~g})$ was extracted with $1.5 \mathrm{~L}$ of $50 \%$ aqueous methanol $(\mathrm{MeOH})$ at room temperature for one day and then filtered. The residues were re-extracted with $0.75 \mathrm{~L} 50 \%$ methanol and then filtered. The combined filtrates were evaporated at $38^{\circ} \mathrm{C}$ under a vacuum. The $50 \% \mathrm{MeOH}$ extracts of $P$. dentata were deposited at $-20^{\circ} \mathrm{C}$ until use in experiment.

\section{Cell culture and differentiation}

3T3-L1 preadipocytes (ATCC ${ }^{\circledR}, \mathrm{CL}-173^{\mathrm{TM}}$ ) were cultured in DMEM (high glucose) supplemented with $10 \% \mathrm{FBS}, 1 \%$ penicillin and streptomycin (Welgene, Gyeongsan, Korea) at $37^{\circ} \mathrm{C}$ in $5 \% \mathrm{CO}_{2}$. For experiment, cells were seeded in 6-well plates at a density of $1.0 \times 10^{5}$ cells/well and grown to confluence. Forty-eight hours after confluence (day 0), adipogenesis was induced by adding differentiation medium (DMEM; high glucose containing 10\% FBS, $0.5 \mathrm{mM} 3$-isobutyl-1-methylxanthine; IBMX, $1 \mu \mathrm{M}$ Dexamethasone; DEX, $1 \mu \mathrm{M}$ Pioglitazone, $10 \mu \mathrm{g} / \mathrm{mL}$ insulin, 
$1 \mu \mathrm{L} / \mathrm{mL}$ dimethyl sulfoxide; DMSO) for $48 \mathrm{~h}$. Every two days, the medium was changed with DMEM; high glucose supplemented 10\% FBS, $10 \mu \mathrm{g} / \mathrm{mL}$ insulin, $1 \mu \mathrm{L} / \mathrm{mL}$ DMSO until 8 days. The pre-adipocytes were maintained and changed medium for every $48 \mathrm{~h}$ with DMEM; high glucose, $10 \% \mathrm{FBS}$, and $1 \mu \mathrm{L} / \mathrm{mL}$ DMSO medium. To investigate the effects of $P$. dentata on adipocyte differentiation, cell culture was treated $P$. dentata $50 \% \mathrm{MeOH}$ extract in different concentrations $(6.25,12.5$, and $25 \mu \mathrm{g} / \mathrm{mL})$ in the differentiation medium for every two days, from the beginning to the end of the experiment. After 5 days of treatment with P. dentata $50 \% \mathrm{MeOH}$ extract. 3T3L1 adipocyte cells were harvested for Real-time quantitative polymerase chain reaction (RT-qPCR) and after 8 days the 3T3-L1 adipocyte cells were fixed in $4 \%$ formalin for Oil Red O staining.

\section{Cell viability assay}

3T3-L1 cells were seeded in 96-well plates at a density of $7.5 \times 10^{2}$ cells/well containing $200 \mu \mathrm{L}$ of 10\% FBS-DMEM; high glucose. After cell seeding, P. dentata $50 \% \mathrm{MeOH}$ extract was added by concentration dependent $(6.25,12.5$, and $25 \mu \mathrm{g} / \mathrm{mL})$. After 24 and $48 \mathrm{hr}$ after addition of the extract, alamarBlue ${ }^{\mathrm{TM}}$ Cell Viability Reagent (ThermoFisher Scientific, Waltham, MA, USA) was added and then fluorescence value was measured by SYNERGY multi-mode reader (BioTek, Seoul, Korea). Viability of cells was measured using alamarBlue assay according manufacturer instructions.

\section{Oil Red O staining of lipid droplets}

To measure the cell lipid droplets, the 3T3-L1 cells were stained with Oil Red O solution. 3T3-L1 cells were washed twice with PBS and adherent cells were fixed in 4\% formalin for $10 \mathrm{~min}$ at room temperature. The $4 \%$ formalin was discarded and fresh $4 \%$ formalin was added and incubated for $1 \mathrm{~h}$ at room temperature. After $1 \mathrm{hr}$, is was washed with tertiary distilled water. The cells were added with 60\% isopropanol and let it stand for $5 \mathrm{~min}$ at room temperature. After $5 \mathrm{~min}, 60 \%$ isopropanol was discarded and the cells were allowed dry completely at room temperature. After drying, $1 \mathrm{ml}$ Oil Red O solution was added to each well and incubated at room temperature for 20 minutes. The cells were washed three times with tertiary distilled water and photographed using a Leica Microscopy, DE/Polyvar SC (Leica, Wetzlar, Germany).

\section{Quantification of adipogenic gene expression using Real-time quantitative poly- merase chain reaction}

Total RNA was isolated from cells using Hybrid $\mathrm{R}^{\mathrm{TM}}$ (GeneAll Biothechnology, Seoul, Korea) including RiboEX ${ }^{\mathrm{TM}}$ treatment of samples to eliminate genomic DNA, protein, and lipid. Quality of RNA was determined by using Nanodrop 2000 spectrophotometer (ThermoFisher Scientific) and RNA gel electrophoresis. cDNA was synthesized from the total RNA using a RevertAid First Strand cDNA Synthesis kit (ThermoFisher Scientific). The real-time PCR was conducted using a CFX96 ${ }^{\mathrm{TM}}$ Real-Time PCR Detection System (Bio rad, Hercules, CA, USA). The level of target gene cDNA was measured by TB Green ${ }^{\circledR}$ Premix EX Taq ${ }^{\text {TM }}$ (Tli Rnase H plus) (Takara Bio, Kosatsu, Japan). All samples were analyzed in triplicate and quantified by the relative standard curve method using the gene expressions of L32 as a housekeeping gene. The sequences of the primer pairs used in this study are listed in Table 1.

\section{Statistical analysis}

Statistical analysis was performed using GraphPad Prism 0.8 (GraphPad Software, San Diego, CA, USA). All the data were analyzed using one-way analysis of variance (ANOVA) with multiple comparisons. Differences between groups were analyzed using $t$-test and values of $p<0.05$ were 
Table 1. Primer sequence used in the RT-qPCR experiment

\begin{tabular}{|c|c|c|}
\hline Gene & Forward (5'-3') & Reverse (3'-5') \\
\hline L32 & TCTGGTGAAGCCCAAGATCG & CTCTGGGTTTCCGCCAGT \\
\hline PPARy2 & GTGCTCCAGAAGATGACAGAC & GGTGGGACTTTCCTGCTAA \\
\hline $\mathrm{C} / \mathrm{EBPa}$ & TGGACAAGAACAGCAACGAG & TCACTGGTCAACTCCAGCAC \\
\hline$A D I P O Q$ & CCGTTCTCTTCACCTACGAC & TCСССАТССССАТАСАС \\
\hline Leptin & TCAАСТСССТGTTTCСAАAT & TCTTCACGAATGTCCCACGA \\
\hline FAS & CCCAGCCCATAAGAGTTACA & ATCGGGAAGTCAGCACAA \\
\hline$a P 2$ & TGGAAGCTTGTCTCCAGTGA & AATCCCCATTTACGCTGATG \\
\hline ACC1 & GACGTTCGCCATAACCAAGT & CTGTTTAGCGTGGGGATGTT \\
\hline
\end{tabular}

considered statistically significant. All experiments were performed triplicate and data were expressed as mean $\pm \mathrm{SEM}$.

\section{RESULTS}

Porphyra dentata 50\% MeOH extract shows no cytotoxicity in 3T3-L1 pre-adipocytes We first performed the alamarBlue assay to test the effect of $P$. dentata $50 \% \mathrm{MeOH}$ extract on cell viability. As shown in Fig. 1, P. dentata $50 \% \mathrm{MeOH}$ extract at $6.25,12.5$, and $25 \mu \mathrm{g} / \mathrm{mL}$ showed no significant effect on cell viability in 3T3L1 mouse preadipocytes after $24 \mathrm{~h}$ and $48 \mathrm{~h}$ treatment. These results indicate that the $P$. dentata $50 \% \mathrm{MeOH}$ extract have no cytotoxicity on cells.

Porphyra dentata $\mathbf{5 0} \% \mathrm{MeOH}$ extract inhibits differentiation and lipid accumulation of 3T3-L1 cells

To investigate the effect of $P$. dentata extract on 3T3-L1 preadipocytes adipogenesis, we treated $P$. dentata extract with various concentrations for 8 days and stained the lipid droplets with Oil Red O during adipocyte differentiation (Fig. 2). Oil Red $\mathrm{O}$ staining assay revealed that $P$. dentata dramatically reduced lipid accumulation in a concentration dependent manner. These results indicate that P. dentata $50 \% \mathrm{MeOH}$ extract suppressed adipocyte differentiation and lipid droplets formation in 3T3-L1 preadipocytes.

A

\section{4h}

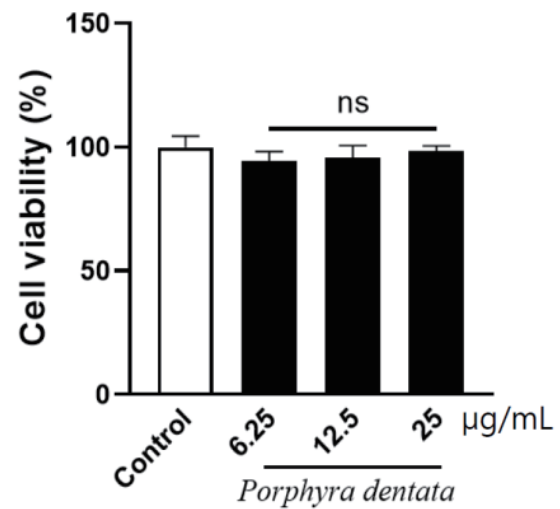

B

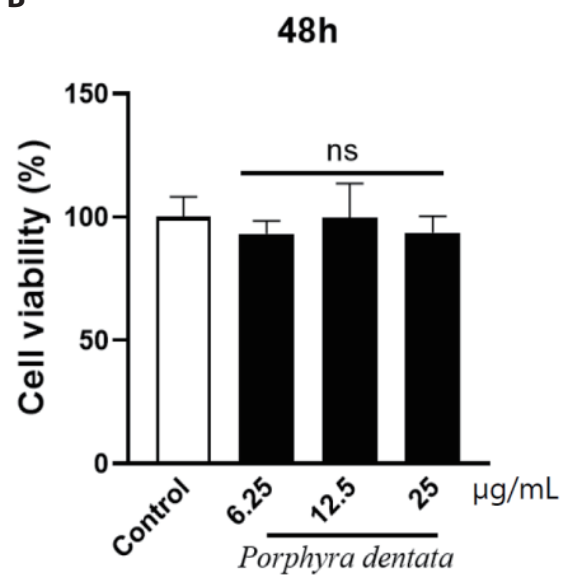

Fig. 1. Cell cytotoxicity of Porphyra dentata 50\% MeOH extract on 3T3-L1 cells. 3T3-L1 cells were treated with different concentrations $(6.25,12.5$, and $25 \mu \mathrm{g} / \mathrm{mL})$ of $P$. dentata $50 \% \mathrm{MeOH}$ extract for detection with alamarBlue assay. 
A

Day 5

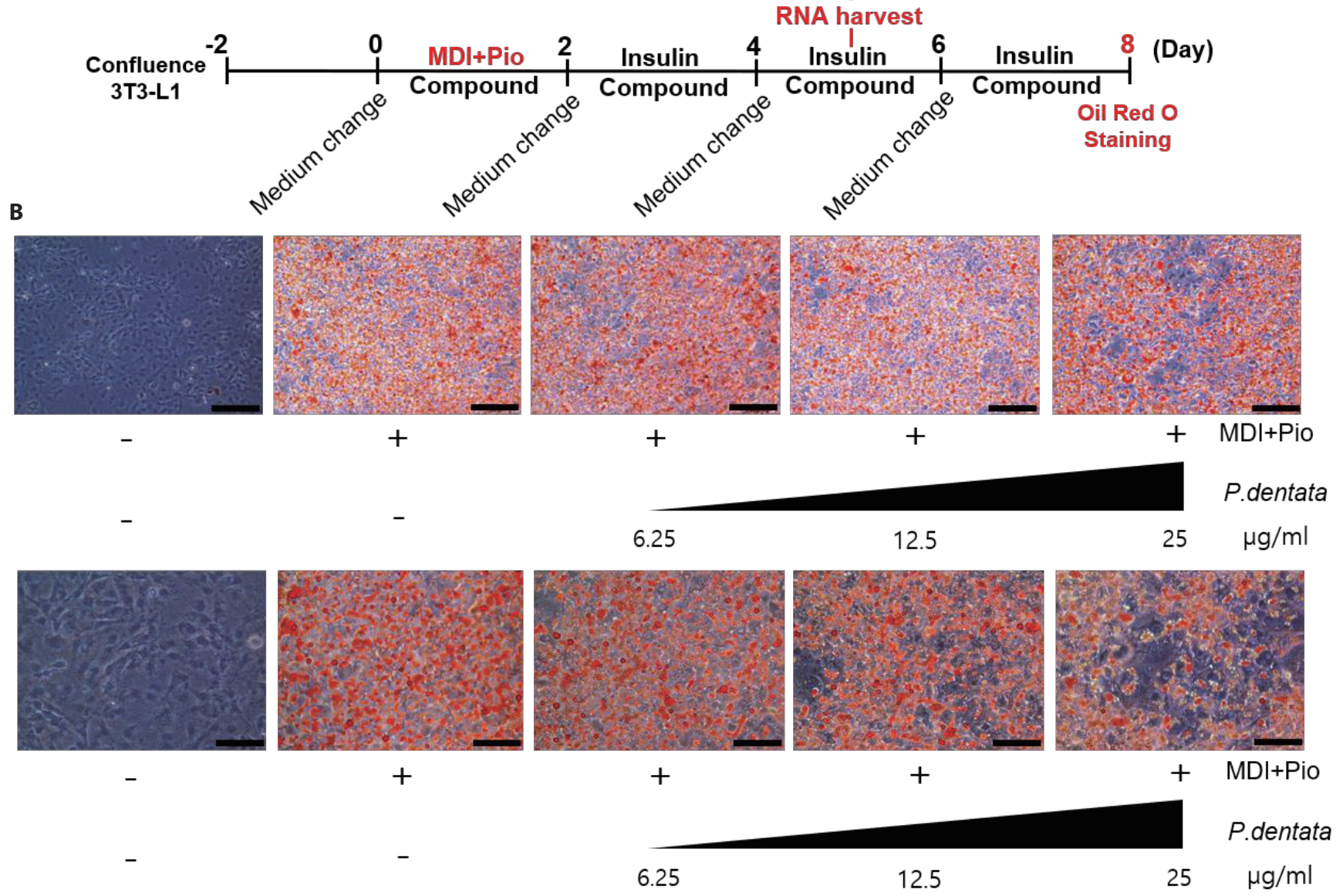

Fig. 2. Decreased accumulation of lipid droplets in differentiated 3T3-L1 cells treatment with Porphyra dentata 50\% MeOH extract. (A) Time schedule of the culture with $P$. dentata $50 \% \mathrm{MeOH}$ extract during the differentiation of 3T3-L1 cells. 3T3-L1 cells reach confluence after 2 days then, added $\mathrm{MDI}+$ pio medium with $P$. dentata $50 \% \mathrm{MeOH}$ extract each of different concentration. The medium with $P$. dentata $50 \% \mathrm{MeOH}$ extract was changed every $48 \mathrm{~h}$ containing $10 \mu \mathrm{g} / \mathrm{mL}$ insulin and $1 \mu \mathrm{g} / \mathrm{mL}$ DMSO until day 8 , followed by staining with Oil Red O. The control 3T3-L1 cells changed every $48 \mathrm{~h}$ to fresh medium with $10 \% \mathrm{FBS}, 1 \mu \mathrm{g} / \mathrm{mL}$ DMSO. (B) Effect of $P$. dentata $50 \% \mathrm{MeOH}$ extract on lipid droplets formation using Oil Red O staining. After 8 days of differentiation, lipid droplet accumulation was stained by Oil Red O staining. Upper panels, scale bar: $100 \mu \mathrm{m}$. Lower panels, scale bar: $50 \mu \mathrm{m}$. MDI, methylisobutylxantine, dexamethasone, insulin; pio, pioglitazone; FBS, Fetal bovine serum; DMSO, dimethyl sulfoxide.

\section{Porphyra dentata $50 \% \mathrm{MeOH}$ extract suppressed the expression of adipocyte dif-} ferentiation marker

Next, we performed RT-qPCR analysis to examine the mRNA expression of adipogenic specific transcription factors such as PPAR- $\gamma 2, \mathrm{C} / \mathrm{EBP} \alpha$, and their target genes such as ADIPOQ, Leptin, FAS, aP2, and ACC1 after the treatment of $P$. dentata $50 \% \mathrm{MeOH}$ extract. The extract decreased the PPAR- $\gamma 2$, C/EBP $\alpha$, as well as ADIPOQ, Leptin, FAS, aP2, and ACC1 mRNA expression. Gene expression of the PPAR- $\gamma 2, \mathrm{C} / \mathrm{EBP} \alpha$, and their adipogenic related genes following P. dentata treatment was significantly lower compared with that of differentiated control adipocytes treated MDI (methylisobutylxanthine, dexamethasone, insulin) plus pioglitazone. P. dentata $50 \% \mathrm{MeOH}$ extract significantly downregulated the expression of adipogenesis associated genes in a dose-dependent manner (Fig. 3).

\section{DISCUSSION}

The 3T3-L1 mouse preadipocytes have been widely used for screening the effective agents to regu- 


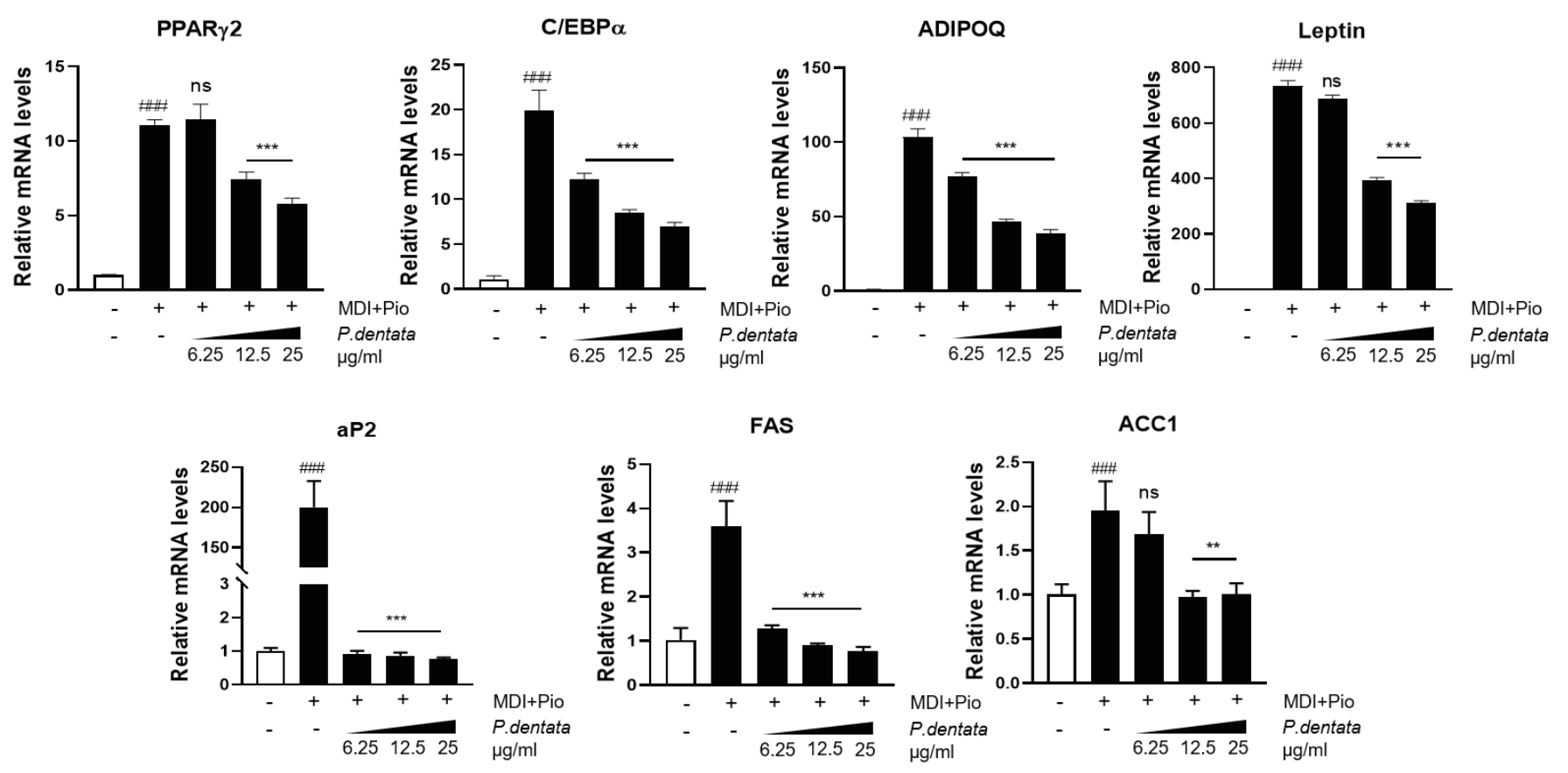

Fig. 3. Expression of adipogenic related genes in 3T3-L1 cells with Porphyra dentata $\mathbf{5 0 \%}$ MeOH extract. The expression of adipogenic related genes which PPAR-y2, C/EBPa (adipogenic transcription factors), ADIPOQ, leptin, aP2 (adipokine), FAS and ACC1 (lipogenic enzyme). 3T3-L1 cells cultured with various concentrations of $P$. dentata $50 \% \mathrm{MeOH}$ extract $(6.25,12.5$, and $25 \mu \mathrm{g} / \mathrm{mL})$ with differentiation media were analyzed on day 5 by RT-qPCR. $P$. dentata $50 \% \mathrm{MeOH}$ extract treatment decreased adipogenic related genes mRNA expression in a concentration-dependent manner on 5 days. Data were presented as mean and standard errors from three experiments. ${ }^{m} p<0.001$ vs. preadipocyte, ${ }^{\prime \prime \prime} p<0.001, " * p<0.01$ vs. MDI+pio. All data are presented as mean \pm SD, and experiments were performed three times. PPARY2, peroxisome proliferator-activated receptor $\mathrm{Y2}$; MDI, methylxanthine, dexamethasone, insulin; C/EBPa, CCAAT/enhancer binding protein $\alpha$; ADIPOQ, adiponectin; aP2, adipocyte protein 2; FAS, fatty acid synthase; ACC1, acetyl-coA carboxylase-1.

late the adipogenesis. The adipogenesis was determined by Oil Red $\mathrm{O}$ staining to show the amount of lipid droplets by specifically staining neutral triglycerides with high levels of adiopocyte-related genes expression in 3T3-L1 cells [22].

In the present study, we demonstrated that $P$. dentata extract dramatically inhibited lipid accumulation during adipocyte differentiation with decreasing PPAR $\gamma 2, \mathrm{C} / \mathrm{EBP} \alpha, \mathrm{ADIPOQ}$, leptin, FAS, aP2, and ACC1 expression. One of the alternative splicing forms of PPAR, PPAR $\gamma 2$, is a lipid-activated transcription factor which specifically expressed in adipose tissue [23]. In response to fatty acids, PPAR $\gamma 2$ leads to fat accumulation in adipocytes by modulating target genes involved in lipid metabolism [24]. However, PPAR $\gamma 2$ does not function alone but cooperatively with transcription factors in the C/EBP family to induce adipocyte differentiation $[9,24]$. The C/EBPs belong to the basic-leucine zipper class of transcription factors and has several forms including $\mathrm{C} / \mathrm{EBP} \alpha$, $\mathrm{C} / \mathrm{EBP} \beta, \mathrm{C} / \mathrm{EBP} \gamma$, and $\mathrm{C} / \mathrm{EBP} \delta$ [25]. The temporal expression of these factors during adipocyte differentiation indicates a cascade whereby early induction of $\mathrm{C} / \mathrm{EBP} \beta$ and $\mathrm{C} / \mathrm{EBP} \delta$ leads to induction of $\mathrm{C} / \mathrm{EBP} \alpha$, which $\mathrm{C} / \mathrm{EBP} \alpha$ induces expression of many adipogenic related genes directly [26]. In this study, the mRNA expression of PPAR $\gamma 2$ and $\mathrm{C} / \mathrm{EBP} \alpha$ decreased significantly after treatment of $P$. dentata extract compared with that in differentiated control cells. It has been reported that PPAR $\gamma 2$ and $\mathrm{C} / \mathrm{EBP} \alpha$ cooperates to increase adipogenic genes using a positive feedback loop between them leading to adipogenesis [27]. ADIPOQ, leptin, and aP2 investigated in this study, are adipokine which cytokine secreted by adipose tissue and in obesity [28,29]. ADIPOQ is an adipocyte-specific factor, which adipocyte-derived hormone, it is abundantly produced and secreted by adipose tissues and widely recognized for its anti-inflammatory effects [30]. Leptin is also 
adipocyte-derived hormone that circulates in proportion to fat mass and acts as a negative regulator of energy homeostasis [31]. aP2 called fatty acid binding protein 4 (FABP4) is one of the only genes characterized by sufficient regulatory sequences to direct adipose-specific expression in vivo $[32,33]$. Having played an important role as adipocytes differentiation marker, as it can lead to the development of increasingly large adipocytes by leptin resistance and contribute to the accumulation of excessive fat masses found in obese states [34]. These adipokine levels were increased during differentiation from preadipocytes to maturation adipocytes $[34,35]$. The other adipogenic related genes, FAS and ACC1 are lipogenic enzymes. FAS is the key enzyme in lipogenesis, catalyzing the reactions for the synthesis of long-chain fatty acids [36]. ACC1 is a multi-subunit lipogenic enzyme that catalyzes the irreversible carboxylation of acetyl-CoA to produce malonyl-CoA for the biosynthesis of fatty acids [37]. Plants have been used as traditional natural medicines for healing many diseases [38] and many studies have shown that plant-derived foods have the potential to reduce obesity [39]. A plant belonging to the genus Porphyra, called laver, also consumed mainly as processed food or used a source of health-enhancing substances and this group have a unique active substances which provide health benefits [39,40]. Porphyra species contain biological active compounds, including polysaccharides, carotenoids, phenolic compounds, and MAAs. These compounds have been reported to have antioxidant [41], anti-inflammatory [42], anti-cancer [43,44], prevention of nervous system [45], and bone disease [46]. In particular, fucoidan, carotenoids, and phenolic compounds (EGCG) inhibited lipid accumulation in 3T3-L1 cells.

Previously, Kim et al. [22] indicated that Pyropia yezoensi (P. yezoensis) methanol extract, one types of laver contain high MAAs content $(120 \mathrm{mg} / \mathrm{g}$ dried extract) reduces the contents of accumulation lipid determined by Oil Red O staining in a dose-dependent manner [22]. However, they demonstrated that treatment with high concentration $(5 \mathrm{mg} / \mathrm{mL})$ of the P. yezoensis methanol extract inhibited adipogenesis with decrease of preadipocytes proliferation via oxidative stress and proapoptotic effects. Our result indicates that $P$. dentata $50 \% \mathrm{MeOH}$ extract at low concentration of $\sim 25 \mu \mathrm{g} / \mathrm{mL}$ significantly suggest anti-adipogenesis in a dose-dependent manner with no cytotoxicity in 3T3-L1 cells. Hence, further study is needed to identify whether bioactive compounds (polysaccharides, carotenoids, phenolics, etc.) contained in laver contribute suppression of lipid accumulation in adipocyte.

In conclusion, $P$. dentata extract inhibited the accumulation of lipid droplets in concentration-dependent manner. Moreover, $P$. dentata extract inhibits the expression of adipogenic related genes involved in the adipogenesis from preadipocytes to mature adipocytes in 3T3-L1 cells. Especially, in all experiments, lipid droplets formation and gene expression are inhibited in a concentration-dependent manner $(6.25,12.5$, and $25 \mu \mathrm{g} / \mathrm{mL})$ of $P$. dentata extract. Thus, the result revealed that $P$. dentata has an effect of anti-obesity that inhibits adipogenesis. Since pharmacological effects of the Porphyra species are proven [47], and P. dentata belonging to that species is also consumed as food, it has the potential to be used as a dietary supplement and medicinal food item to suppress obesity.

\section{REFERENCES}

1. Heymsfield SB, Wadden TA. Mechanisms, pathophysiology, and management of obesity. N Engl J Med. 2017;376:254-66. https://doi.org/10.1056/NEJMra1514009

2. Khandekar MJ, Cohen P, Spiegelman BM. Molecular mechanisms of cancer development in obesity. Nat Rev Cancer. 2011;11:886-95. https://doi.org/10.1038/nrc3174

3. Kim GC, Kim JS, Kim GM, Choi SY. Anti-adipogenic effects of Tropaeolum majus (nasturtium) ethanol extract on 3T3-L1 cells. Food Nutr Res. 2017;61:1339555. https://doi.org/10.10 80/16546628.2017.1339555 
4. González-Castejón M, Rodriguez-Casado A. Dietary phytochemicals and their potential effects on obesity: a review. Pharmacol Res. 2011;64:43855. https://doi.org/10.1016/ j.phrs.2011.07.004

5. Hammarstedt A, Gogg S, Hedjazifar S, Nerstedt A, Smith U. Impaired adipogenesis and dysfunctional adipose tissue in human hypertrophic obesity. Physiol Rev. 2018;98:1911-41. https:// doi.org/10.1152/physrev.00034.2017

6. Cao Y. Angiogenesis modulates adipogenesis and obesity. J Clin Invest. 2007;117:2362-8. https://doi.org/10.1172/JCI32239

7. Spiegelman BM, Flier JS. Adipogenesis and obesity: rounding out the big picture. Cell. 1996;87:377-89. https://doi.org/10.1016/S0092-8674(00)81359-8

8. Shao D, Lazar MA. Peroxisome proliferator activated receptor $\gamma$, CCAAT/enhancer-binding protein $\alpha$, and cell cycle status regulate the commitment to adipocyte differentiation. J Biol Chem. 1997;272:21473-8. https://doi.org/10.1074/jbc.272.34.21473

9. Auwerx J, Martin G, Guerre-Millo M, Staels B. Transcription, adipocyte differentiation, and obesity.J Mol Med. 1996;74:347-52. https://doi.org/10.1007/BF00210629

10. Moseti D, Regassa A, Kim WK. Molecular regulation of adipogenesis and potential anti-adipogenic bioactive molecules. Int J Mol Sci. 2016;17:124. https://doi.org/10.3390/ijms17010124

11. Holdt SL, Kraan S. Bioactive compounds in seaweed: functional food applications and legislation. J Appl Phycol. 2011;23:543-97. https://doi.org/10.1007/s10811-010-9632-5

12. Yoshiki M, Tsuge K, Tsuruta Y, Yoshimura T, Koganemaru K, Sumi T, et al. Production of new antioxidant compound from mycosporine-like amino acid, porphyra-334 by heat treatment. Food Chem. 2009;113:1127-32. https://doi.org/10.1016/j.foodchem.2008.08.087

13. Rui Y, Zhaohui Z, Wenshan S, Bafang L, Hu H. Protective effect of MAAs extracted from Porphyra tenera against UV irradiation-induced photoaging in mouse skin. J Photochem Photobiol B. 2019;192:26-33. https://doi.org/10.1016/j.jphotobiol.2018.12.009

14. Isaka S, Cho K, Nakazono S, Abu R, Ueno M, Kim D, et al. Antioxidant and anti-inflammatory activities of porphyran isolated from discolored nori (Porphyra yezoensis). Int J Biol Macromol. 2015;74:68-75. https://doi.org/10.1016/j.ijbiomac.2014.11.043

15. Wang $X$, Zhang $Z$. The antitumor activity of a red alga polysaccharide complexes carrying 5-fluorouracil. Int J Biol Macromol. 2014;69:542-5. https://doi.org/10.1016/j.ijbiomac.2014.06.017

16. Wan-Loy C, Siew-Moi P. Marine algae as a potential source for anti-obesity agents. Mar Drugs. 2016;14:222. https://doi.org/10.3390/md14120222

17. Gómez-Zorita S, González-Arceo M, Trepiana J, Eseberri I, Fernández-Quintela A, Milton-Laskibar I, et al. Anti-obesity effects of macroalgae. Nutrients. 2020;12:2378. https://doi. org $/ 10.3390 / n u 12082378$

18. Rodríguez-Pérez C, Segura-Carretero A, del Mar Contreras M. Phenolic compounds as natural and multifunctional anti-obesity agents: a review. Crit Rev Food Sci Nutr. 2019;59:1212-29. https://doi.org/10.1080/10408398.2017.1399859

19. Kim KJ, Lee BY. Fucoidan from the sporophyll of Undaria pinnatifida suppresses adipocyte differentiation by inhibition of inflammation-related cytokines in 3T3-L1 cells. Nutr Res. 2012;32:439-47. https://doi.org/10.1016/j.nutres.2012.04.003

20. Cho TJ, Rhee MS. Health functionality and quality control of laver (Porphyra, Pyropia): current issues and future perspectives as an edible seaweed. Mar Drugs. 2019;18:14. https://doi. org/10.3390/md18010014

21. Kazłowska K, Hsu T, Hou CC, Yang WC, Tsai GJ. Anti-inflammatory properties of phenolic compounds and crude extract from Porphyra dentata. J Ethnopharmacol. 2010;128:123-30. 
https://doi.org/10.1016/j.jep.2009.12.037

22. Kim H, Lee Y, Han T, Choi EM. The micosporine-like amino acids-rich aqueous methanol extract of laver (Porphyra yezoensis) inhibits adipogenesis and induces apoptosis in 3T3-L1 adipocytes. Nutr Res Pract. 2015;9:592-8. https://doi.org/10.4162/nrp.2015.9.6.592

23. de Sá PM, Richard AJ, Hang H, Stephens JM. Transcriptional regulation of adipogenesis. Compr Physiol. 2017;7:635-74. https://doi.org/10.1002/cphy.c160022

24. Tontonoz P, Hu E, Graves RA, Budavari AI, Spiegelman BM. mPPARy2: tissue-specific regulator of an adipocyte enhancer. Genes Dev. 1994;8:1224-34. https://doi.org/10.1101/ gad.8.10.1224

25. Rosen ED, Walkey CJ, Puigserver P, Spiegelman BM. Transcriptional regulation of adipogenesis. Genes Dev. 2000;14:1293-307.

26. Rosen ED, MacDougald OA. Adipocyte differentiation from the inside out. Nat Rev Mol Cell Biol. 2006;7:885-96. https://doi.org/10.1038/nrm2066

27. Wu Z, Rosen ED, Brun R, Hauser S, Adelmant G, Troy AE, et al. Cross-regulation of C/ $\mathrm{EBP} \alpha$ and PPAR $\gamma$ controls the transcriptional pathway of adipogenesis and insulin sensitivity. Mol Cell. 1999;3:151-8. https://doi.org/10.1016/S1097-2765(00)80306-8

28. Ghantous CM, Azrak Z, Hanache S, Abou-Kheir W, Zeidan A. Differential role of leptin and adiponectin in cardiovascular system. Int J Endocrinol. 2015;2015:534320. https://doi. org $/ 10.1155 / 2015 / 534320$

29. Li Y, Rong Y, Bao L, Nie B, Ren G, Zheng C, et al. Suppression of adipocyte differentiation and lipid accumulation by stearidonic acid (SDA) in 3T3-L1 cells. Lipids Health Dis. 2017;16:181. https://doi.org/10.1186/s12944-017-0574-7

30. Fang H, Judd RL. Adiponectin regulation and function. Compr Physiol. 2018;8:1031-63. https://doi.org/10.1002/cphy.c170046

31. Bell BB, Rahmouni K. Leptin as a mediator of obesity-induced hypertension. Curr Obes Rep. 2016;5:397-404. https://doi.org/10.1007/s13679-016-0231-x

32. Cao H, Sekiya M, Ertunc ME, Burak MF, Mayers JR, White A, et al. Adipocyte lipid chaperone $\mathrm{aP} 2$ is a secreted adipokine regulating hepatic glucose production. Cell Metab. 2013;17:768-78. https://doi.org/10.1016/j.cmet.2013.04.012

33. Tontonoz P, Hu E, Spiegelman BM. Stimulation of adipogenesis in fibroblasts by PPAR $\gamma 2$, a lipid-activated transcription factor. Cell. 1994;79:1147-56. https://doi.org/10.1016/00928674(94)90006-X

34. Sáinz N, Barrenetxe J, Moreno-Aliaga MJ, Martínez JA. Leptin resistance and diet-induced obesity: central and peripheral actions of leptin. Metabolism. 2015;64:35-46. https://doi. org/10.1016/j.metabol.2014.10.015

35. Simons PJ, van den Pangaart PS, van Roomen CPAA, Aerts JMFG, Boon L. Cytokine-mediated modulation of leptin and adiponectin secretion during in vitro adipogenesis: evidence that tumor necrosis factor- $\alpha$ - and interleukin- $1 \beta$-treated human preadipocytes are potent leptin producers. Cytokine. 2005;32:94-103. https://doi.org/10.1016/j.cyto.2005.08.003

36. Hogan JC, Stephens JM. The regulation of fatty acid synthase by STAT5A. Diabetes. 2005;54:1968-75. https://doi.org/10.2337/diabetes.54.7.1968

37. Yang SM, Park YK, Kim JI, Lee YH, Lee TY, Jang BC. LY3009120, a pan-Raf kinase inhibitor, inhibits adipogenesis of 3T3-L1 cells by controlling the expression and phosphorylation of C/EBP- $\alpha$, PPAR- $\gamma$, STAT-3, FAS, ACC, perilipin A, and AMPK. Int J Mol Med. 2018;42:3477-84. https://doi.org/10.3892/ijmm.2018.3890

38. Roh C, Jung U. Screening of crude plant extracts with anti-obesity activity. Int J Mol Sci. 2012;13:1710-9. https://doi.org/10.3390/ijms13021710 
39. Boeing H, Bechthold A, Bub A, Ellinger S, Haller D, Kroke A, et al. Critical review: vegetables and fruit in the prevention of chronic diseases. Eur J Nutr. 2012;51:637-63. https://doi. org/10.1007/s00394-012-0380-y

40. Rajapakse N, Kim SK. Nutritional and digestive health benefits of seaweed. Adv Food Nutr Res. 2011;64:17-28. https://doi.org/10.1016/B978-0-12-387669-0.00002-8

41. Zhang Z, Zhang Q, Wang J, Zhang H, Niu X, Li P. Preparation of the different derivatives of the low-molecular-weight porphyran from Porphyra haitanensis and their antioxidant activities in vitro. Int J Biol Macromol. 2009;45:22-6. https://doi.org/10.1016/j.ijbiomac.2009.03.009

42. Yanagido A, Ueno M, Jiang Z, Cho K, Yamaguchi K, Kim D, et al. Increase in anti-inflammatory activities of radical-degraded porphyrans isolated from discolored nori (Pyropia yezoensis). Int J Biol Macromol. 2018;117:78-86. https://doi.org/10.1016/j.ijbiomac.2018.05.146

43. Yu X, Zhou C, Yang H, Huang X, Ma H, Qin X, et al. Effect of ultrasonic treatment on the degradation and inhibition cancer cell lines of polysaccharides from Porphyra yezoensis. Carbohydr Polym. 2015;117:650-6. https://doi.org/10.1016/j.carbpol.2014.09.086

44. Noda H, Amano H, Arashima K, Nisizawa K. Antitumor activity of marine algae. Hydrobiologia. 1990;204:577-84. https://doi.org/10.1007/BF00040290

45. Mohibbullah M, Bhuiyan MMH, Hannan MA, Getachew P, Hong YK, Choi JS, et al. The edible red alga Porphyra yezoensis promotes neuronal survival and cytoarchitecture in primary hippocampal neurons. Cell Mol Neurobiol. 2016;36:669-82. https://doi.org/10.1007/s10571015-0247-x

46. Ueno M, Cho K, Isaka S, Nishiguchi T, Yamaguchi K, Kim D, et al. Inhibitory effect of sulphated polysaccharide porphyran (isolated from Porphyra yezoensis) on RANKL-induced differentiation of RAW264.7 cells into osteoclasts. Phytother Res. 2018;32:452-8.

47. Venkatraman KL, Mehta A. Health benefits and pharmacological effects of Porphyra species. Plant Foods Hum Nutr. 2019;74:10-7. https://doi.org/10.1007/s11130-018-0707-9 